\title{
Futbol Hakemlerini Strese İten Faktörler, İş Tatmini ve İş Performansı İlişkisinin İncelenmesi*
}

\author{
Serdar KOCA ${ }^{1 \dagger}$, Süleyman Murat YILDIZ ${ }^{2}$ \\ ${ }^{1}$ Bilim Uzmanl, https://orcid.org/0000-0002-0068-8648. \\ ${ }^{2}$ Muğla Sitkı Koçman Üniversitesi, Spor Bilimleri Fakültesi, https://orcid.org/0000-0002-5335-3593.
}

$\ddot{\mathbf{O} z}$

Orijinal Makale

$\mathrm{Bu}$ araştırma, futbol hakemlerinin stres kaynakları, iş tatmini ve iş performansı ilişkisinin incelenmesi amacıyla gerçekleştirilmiştir. Veri toplama aracı olarak; hakemleri strese iten faktörler, iş tatmini ve iş performansı ölçekleri kullanılmıştır. İş tatminini ölçmede Chang ve Chang'ın (2007) iş tatmini ölçeği futbol hakemlerine uyarlanarak kullanılmıştır. Futbol hakemlerini strese iten faktörler ile futbol hakemlerine yönelik iş performansı ölçeği bu araştırmada geliştirilmiştir. Strese iten faktörler 14 madde ve 3 boyuttan (dışsal faktörler, DOI: 10.25307/jssr.334624 sosyal faktörler ve kişisel faktörler) oluşmuştur. İş performansı ölçeği 6 maddeden ve tek boyuttan oluşmuştur. Araştırmada kullanılan veriler Muğla ve Giresun illerindeki futbol hakemlerinden $(n=140)$ elde edilmiştir. Verilerin analizinde, betimleyici analiz, geçerlik ve güvenirlik analizi, korelasyon analizi ve regresyon analizi kullanılmıştır. Araştırmanın sonucu strese iten faktörlerin futbol hakemlerinin iş tatmini ve iş performansını negatif olarak etkilediğini göstermiştir. Diğer taraftan, iş tatmininin strese iten faktörler ile iş performans1 arasında "aracılık etkisinin bulunmadığını" da göstermiştir.

Anahtar kelimeler:

Futbol hakemi

İs performanst

\section{An Investigation of Relationships among Stress Resources of Football Referees, Job Satisfaction and Job Performance}

\begin{tabular}{lr} 
Abstract & Original Article \\
\hline This research was conducted in order to investigate of relationships among stress resources of & Article Info \\
football referees, job satisfaction and job performance. To measure stress resources of football & Received: 14.08 .2017 \\
referees, job satisfaction and job performance scales were used. To measure job satisfaction of & Accepted: 14.10 .2018 \\
referees, the job satisfaction scale developed by Chang and Chang (2007) was used. Stress \\
resources of football referees and job performance scales were developed in this research. \\
$\begin{array}{l}\text { Stress resources of football referees scale included } 14 \text { items and 3 dimensions (external } \\
\text { factors, social factors and personal factors). On the other hand, job performance scale included }\end{array}$ \\
6 items and one dimension. Data was gathered from a sample of football referees (n=140) in \\
Mugla and Giresun, Turkey. Descriptive statistic, validity and reliability analysis, correlation \\
analysis and regression analysis were utilized for the evaluation of data. The study showed \\
that stress resources of football referees had a significant and negative effect on job \\
satisfaction and job performance. The study also showed that there was no mediating role of \\
stress resources of football referees between job satisfaction and job performance. & Football referee, \\
& Stress, \\
\end{tabular}

*Bu çalışma Muğla Sıtkı Koçman Üni. Sağlık Bilimler Enstitüsü Beden Eğitimi ve Spor Anabilim Dalında Serdar Koca tarafından hazırlanan

"futbol hakemlerini strese iten faktörler, iş tatmini ve iş performansı ilişkisinin incelenmesi”" isimli yüksek lisans tezinden türetilmiştir.

† Sorumlu Yazar: Serdar KOCA, E-mail: serdarkoca_44@hotmail.com 
Koca, S., ve Yıldız, S.M. (2018). Futbol hakemlerini strese iten faktörler, iş tatmini ve iş performansı ilişkisinin incelenmesi. Spor Bilimleri Araştırmaları Dergisi, 3(2), 195-207.

\section{GİRIŞ}

Günümüzde spor branşları içerisinde popüler olan futbol, toplumun geniş ilgisini çekerek spor gündeminde ilk sıralarda yer almaktadır. Futbol takımlarının performansları ve maç sonuçları spor medyasında ve spor kamuoyunda geniş bir şekilde değerlendirilmektedir. Gerek futbol oyununun içinde gerekse oyunun dışında hakemlerin performansı takımların performansı ve maç sonucu kadar gündeme gelmektedir. Bu durum hakemlerin yaptıkları işin ne kadar hassas olduğunu ortaya koymaktadır.

Futbol hakemleri mesleklerini icra ederken, fiziksel durumlar, maçın önemi, seyirci baskısı, hava muhalefeti, maç güvenliği gibi iş tatmini ve iş performansını etkileyen unsurlarla karşı karşıya kalmaktadırlar. Bu unsurlar futbol maçlarının seyir kalitesini ve takımların ekonomik ve sosyal durumlarını etkilediğinden, bu konuların araştırılması önemli görülmektedir.

Takımların yüksek performansları ve galibiyetleri takım üyelerine maddi kazanç, taraftarlarına da haz ve psikolojik üstünlük sağlamaktadır (Yıldız, 2015b). Hakemlerin futbol oyununun doğal akışını bozacak kararlar vermesi, maç sonuçlarını ciddi derecede etkilediğinden, bu durum takımların maddi kayıplarına ve taraftarların psikolojik üstünlügü kaybetmesine ve dolayısıyla yoğun eleştirilere yol açmaktadır. Hakemlerin performansı futbol oyun zevkini ve kalitesini etkilediğinden, hakemleri de etkileyen faktörlerin neler olduğu ve bu faktörlerin diğer değişkenlerle ilişkisinin bilinmesi bu araştırmanın temel amacını oluşturmaktadır. $\mathrm{Bu}$ amaç çerçevesinde bu araştırmada stres, iş tatmini ve iş performansı ele alınmıştır.

\section{Stres}

Futbol hakemlerini etkileyen faktörlerin başında stres gelmektedir. Bununla beraber, iş tatmini ve iş performansı da doğrudan futbol hakemlerini, dolaylı olarak da futbol çevresini (futbolcu, taraftar vb.) etkileyebilmektedir. Stres kavramı, sanayileşen her toplumdaki bireylerin öğrenip kullandığ 1 psikolojik kavramlardan biridir. Çalışma yaşamında stres yaratan birçok psikososyal faktör vardır. Bu psiko-sosyal faktörler, organizasyon yapısı, işin yapısı ve içeriği, organizasyon içi insan ilişkileri ile yakından ilişkilidir. Stres yaratan faktörler grubu aralarında etkileşerek, insanların ruhsal ve fiziksel yapılarını etkilerler. Bu etkileme insanlar arası ilişkileri olumsuz etkileyebileceği gibi, insanlarda yüksek bir motivasyona da neden olabilir. Bireyin psikolojik varlığını, kendine olan güven ve saygısını zorlayan bütün faktörler onda stres yaratır. Başka bir ifade ile stres, insanın dengesini bozabilecek bütün unsurları kapsayan bir özelliğe sahiptir (Güney, 2012:405).

Stres, organizmanın mücadele gerektiren veya tehdit edici bir durumla karşılaştığında, bu durumla mücadele ederek içsel dengeyi korumaya çalışmasıdır (Tiryaki, 2000:18). Aşırı stresin çalışanlar üzerinde fizyolojik, psikolojik ve davranışsal olmak üzere bir takım olumsuz durumlara neden olmaktadır. Fizyolojik olarak uykusuzluk, iştahsızlık, baş ağrısı; psikolojik olarak depresyon, dikkat dağınıklığı ve tükenme; çevreye karşı duyarsızlaşma, çalışmada hatalar örnek olarak verilebilir (Schermerhorn ve diğ., 1988). Çalışma yaşamında stresin organizasyon üzerinde de bir takım olumsuz etkileri vardır. Performans ve verimlilikte düşüklük, bağlılığın azalması, iş hatalarının artması, işten ayrılma niyetinin artması gibi durumlar, stresin organizasyon üzerindeki etkilerinden bazılarıdır (Gümüştekin ve Öztemiz, 2005).

\section{İş Tatmini}

Çalışanlar bir iş ortamında bireysel amaçlarını gerçekleştirmek üzere zihinsel, fiziksel ve sosyal becerilerini sergilerler. Bu süreç içerisinde, iş ve iş ortamı kaynaklı, kişide duygusal olarak bir takım tepkiler meydana gelir. Bunlar zamanla doğrudan çalışanın, dolaylı olarak da 
işletmenin performansını olumlu veya olumsuz etkiler. Bu yüzden iş tatmini, işletmeler için önemli görülen olgular arasında yer almaktadır (Yıldız, 2015a:77). İş tatmini, çalışanın çalışma koşullarını ve işinin özelliklerini değerlendirmesi sonucu zihninde oluşan duygu durumudur. Bir başka tanıma göre iş tatmini, çalışanın işten beklentisi ile iş yerinin kendisine sunduğu imkanları değerlendirmesi sonucundaki farka göre oluşan duygu durumudur. Buna göre, eğer iş yeri çalışanın beklentisini karşıllyorsa iş tatmini, aksi durumda iş tatminsizliği oluşmaktadır (Aziri, 2011). Çalışanların işinden tatmin ve mutlu olması, iş verimliliğinin ve yüksek iş performansının yolunu açmakta, organizasyonuna daha fazla bağlanmasına neden olmaktadır. Böylece çalışanların işte kalma arzuları artmaktadır. Organizasyonunun iyiliği için daha fazla çaba harcayan çalışanlar, organizasyonunun lehine ve beklentilerin ötesinde davranışlar sergilemekte, güçlükler karşısında toleranslı olmakta, organizasyonun politikalarını ve gelişimini desteklemektedirler (Yıldız, 2015a:78).

\section{İş Performansı}

İş performansı, hedeflenen bir işin ne derecede yapıldığını betimleyen bir kavramdır. Bireysel açıdan bakıldığında iş performansı, organizasyonun hedefine ulaşma çabasına katkı sağlamak amacıyla çalışanın gösterdiği davranışlardır (Sonnentag ve Frese, 2002:375). İş performansının ortaya çıkmasında kapasite, isteklilik ve çevre unsurları etkili olmaktadır. Kapasite, işin gereklerine uygun özellikleri ifade eder. Bu boyut; yetenek, yaş, sağlık, bilgi, beceri, zeka, eğitim düzeyi, dayanıklılık, enerji düzeyi, motor becerilerden oluşmaktadır. Bir işi, nasıl ve ne şekilde yapacağını bilemeyen, yerine getirecek potansiyeli ve özellikleri olmayan bir çalı̧̧andan istenen performans beklemek mümkün değildir. İsteklilik, çalışanın işin gereği olan çabayı gösterme isteğidir. Bu boyut; motivasyon, tatmin, iş statüsü, anksiyete, tutum, algılanan görev özellikleri, kişilik, normlar, algılanan rol beklentisi, adalet hissi değiş̧kenlerinden oluşmaktadır. Bir çalışanın her ne kadar kapasitesi uygun olsa da, isteklilik olmadığı sürece beklenen performans gerçekleşmeyecektir. Çevre unsurları (firsatlar), işin gerçekleşmesi için çevre unsurların varlığıdır. Ekipmanlar, kaynaklar, iş koşulları, çalışma arkadaşı iliş̧kileri, lider davranışları, mentorlük, örgütsel politikalar, kurallar ve prosedürler, bilgi, zaman ve ödeme çevre unsurları içerisine girer. Çalışanın kapasitesi ve istekliliği uygun olsa da, çevre unsurları uygun olmadığı sürece yine çalışandan yüksek performans beklenemez. Özetle iş performansı, iş tanımına ve verilen role uygun olarak, çalışanın kapasitesini ve istekliliğini ortaya koymak suretiyle gösterdiği çabalar ile iş çevresindeki unsurların desteği sonucunda ortaya çıkmaktadır (Yıldız, 2015a:75). İş performansının organizasyonun amaç ve hedeflerini gerçekleştirmesinde önemli rolü bulunmaktadır. Ayrıca, çalışanların yüksek performansı işleri kolaylaş̧ırmakta, sağlıklı insan ilişkileri oluşmasına katkı sağlamakta, müşterilere daha kaliteli hizmetin yolunu açmaktadır (Yıldız, 2015a:76).

\section{YÖNTEM}

\section{Araştırmanın Modeli}

Futbol hakemlerini strese iten faktörler, iş tatmini ve iş performansı ilişkisinin incelenmesi amacıyla yapılan bu araştırmanın modeli Şekil 1'de sunulmuştur. Bu model değişkenler arasında neden sonuç ilişkisini, yani bağımsız değişkenin aracı değişkene, bağımsız değiş̧enin bağımlı değişkene ve aracı değişkenin bağımlı değiş̧ene olan etkisini göstermektedir. Burada aracı değişkenin etkisi kontrol edildiğinde bă̆ımsız değişken ile bağımlı değişken arasındaki ilişkinin düzeyine bakılır. İlişki düzeyinde düşüş olması ve anlamlılı̆ı̆ devam etmesi "kısmi aracılığı", ilişkinin anlamlı çıkmaması ise "tam aracılı̆̆ı" 
gösterir. Diğer taraftan aracı değişken ile bağımlı değişken arasındaki anlamlılık düzeyinin de korunmas1 gerekir (Baron ve Kenny, 1986).

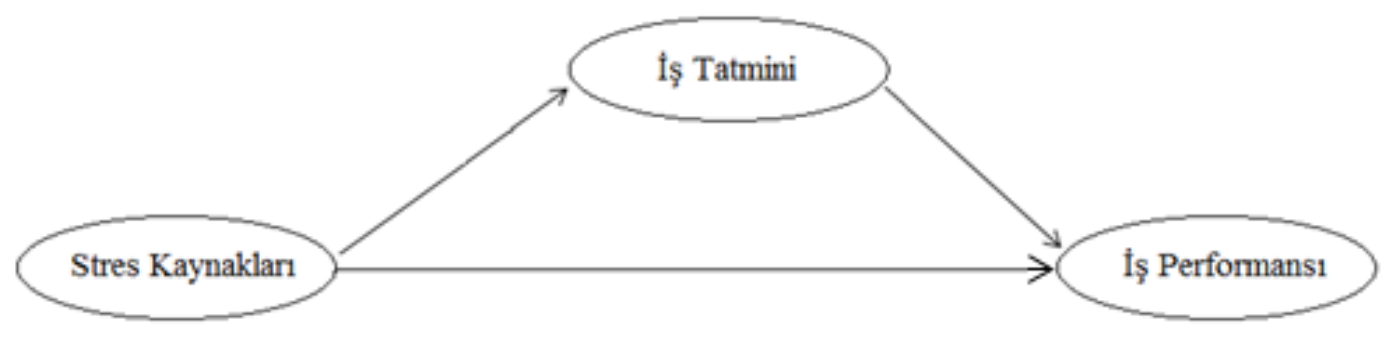

Şekil 1. Strese iten faktörler, iş tatmini, iş performansı ilişkisi

Biyolojik, psikolojik ve sosyal özelliklere sahip olan futbol hakemleri, diğer insanlar gibi, içsel ve dişsal unsurlardan etkilenmektedir. Dolayısıyla futbol hakemlerini strese iten faktörlerin belirlenmesi ve bu faktörlerin iş tatmini ve iş performansı ile ilişkisinin incelenmesinin amaçlandığı bu araştırmada aşağıdaki hipotezler geliştirilmiştir:

$\mathrm{H}_{1}$ : Strese iten faktörlerin futbol hakemlerinin iş tatminini ile anlamlı ve negatif ilişkisi vardır.

$\mathrm{H}_{2}$ : Strese iten faktörlerin futbol hakemlerinin iş performansı ile anlamlı ve negatif ilişkisi vardir.

$\mathrm{H}_{3}$ : İş tatminin, strese iten faktörler ile iş performansı arasında aracılık etkisi vardır.

\section{Evren ve Örneklem}

$\mathrm{Bu}$ araştırmanın çalışma evrenini Muğla ve Giresun illeri oluşturmaktadır. Ölçek formları il hakem kurulu başkanlığından alınan yazılı izin ile futbol hakemlerinden elde edilmiştir. Ölçek formları 200 futbol hakemine gerekli açıklamalar yapılarak dağıtılmıştır. Formlar gizliliğe riayet edilerek iki hafta sonra toplanmıştır. Toplanan form sayısı 154 olarak gerçekleşmiş, sonuçta \% 77'lik geri dönüş oranı elde edilmiştir. 14 ölçek formu eksik ve hatalı doldurulduğundan analize dahil edilmemiştir. Sonuç olarak araştırmada kullanılabilir ölçek sayısı 140 olarak gerçekleşmiştir.

\section{Veri Toplama Araçlart}

$\mathrm{Bu}$ araştırmada veri toplama aracı olarak; futbol hakemlerini strese iten faktörler, iş tatmini ve iş performansı ölçekleri kullanılmıştır. İş tatminini ölçmede Chang ve Chang'ın (2007) iş tatmini ölçeği futbol hakemlerine uyarlanarak kullanılmıştır. Futbol hakemlerini strese iten faktörler ölçeği ile futbol hakemleri iş performansı ölçeği bu araştırmada geliştirilmiştir. Futbol hakemlerini strese iten faktörler ile futbol hakemlerinin iş performansını ölçecek maddeleri belirleyebilmek için 10 futbol hakemi ile Carson ve diğerlerinin (2001:85) önerdiği derinlemesine görüşmeler yapılmıştır. Görüşmeye katılan hakemlere "mesleğinizde sizi strese iten faktörler nelerdir?", "iş performansınızı ne şekilde ifade edersiniz?" soruları sorulmuştur. Madde havuzu oluşturularak arka arkaya bir dizi görüşme gerçekleştirilmiş ve görüşmeler doyum noktasına ulaştığında sonlandırılmıştır. Sonuçta strese iten faktörler için 15 madde, iş performansı için 6 madde üretilmiştir. Bu maddeler ölçeklerin kapsam geçerliliği için 4 üst düzey futbol hakemine incelettirilmiş ve küçük düzeltmeler yapıldıktan sonra uygulama formu haline getirilmiştir. Her üç ölçekteki ifadeler ("1=Hiç katılmıyorum", "2=Katılmıyorum", "3=Kararsızım", "4=Kat1lıyorum", "5=Tamamen kat1liyorum"dan oluşan) 5'li derece ile ölçülmüştür. 
Koca, S., ve Yıldız, S.M. (2018). Futbol hakemlerini strese iten faktörler, iş tatmini ve iş performansı ilişkisinin incelenmesi. Spor Bilimleri Araştırmaları Dergisi, 3(2), 195-207.

\section{Verilerin Değgerlendirilmesi}

Ölçeklerin önce yapı geçerliliği ve güvenirliği test edilmiştir. Geçerlilik için açımlayıcı faktör analizi uygulanmış ve faktör yükleri 0,40 'tan yukarı olan maddeler dikkate alınmıştır. Güvenirlik için Cronbach Alpha katsayısı hesaplanmıştır. Ardından değişkenler arasındaki ilişkileri belirlemek için korelasyon analizi; iş tatmininin, stres faktörleri ile iş performansı arasındaki aracılık etkisini tespit edebilmek için de hiyerarşik regresyon analizi uygulanmıştır.

\section{BULGULAR}

\section{Demografik Özellikler}

Araştırmaya katılan futbol hakemlerinin demografik özellikleri Tablo 1'de görülmektedir.

Tablo 1: Futbol hakemlerinin demografik özelliklerine göre dağılımları

\begin{tabular}{|c|c|c|}
\hline Cinsiyet & f & $\%$ \\
\hline Erkek & 106 & 75.7 \\
\hline Kadın & 34 & 24.3 \\
\hline Toplam & 140 & 100 \\
\hline Medeni Durum & f & $\%$ \\
\hline Evli & 16 & 11.4 \\
\hline Bekar & 124 & 88.6 \\
\hline Toplam & 140 & 100 \\
\hline Ĕgitim Durumu & $\mathbf{f}$ & $\%$ \\
\hline Lise & 28 & 20 \\
\hline Üniversite & 112 & 80 \\
\hline Toplam & 140 & 100 \\
\hline Meslek & f & $\%$ \\
\hline Öğrenci & 94 & 67.1 \\
\hline Memur & 31 & 22.1 \\
\hline Öğretmen & 15 & 10.7 \\
\hline Toplam & 140 & 100 \\
\hline Gelir & f & $\%$ \\
\hline 1300 TL ve alt1 & 87 & 62.1 \\
\hline $1301-2300 \mathrm{TL}$ & 28 & 20 \\
\hline 2301-3300 TL & 14 & 10 \\
\hline $3301-4300 \mathrm{TL}$ & 6 & 4.3 \\
\hline 4301 TL ve üstü & 5 & 3.6 \\
\hline Toplam & 140 & 100 \\
\hline Klasman & f & $\%$ \\
\hline Aday hakem & 64 & 45.7 \\
\hline İl hakemi & 48 & 34.3 \\
\hline Bölgesel yardımcı hakem & 10 & 7.1 \\
\hline Bölgesel hakem & 6 & 4.3 \\
\hline Ulusal yardımcı hakem & 6 & 4.3 \\
\hline Ulusal hakem & 3 & 2.1 \\
\hline Üst klasman yardımcı hakem & 2 & 1.4 \\
\hline Üst klasman hakem & 1 & 0.7 \\
\hline Toplam & 140 & 100 \\
\hline Diğer Değişkenler & $\mathbf{X}$ & SS \\
\hline Yaş & 23.83 & 4.66 \\
\hline Hakemlik y1lı & 1.87 & 1.41 \\
\hline
\end{tabular}

Futbol hakemlerinin demografik özelliklerine göz atıldığında, hakemlerin büyük çoğunluğunun erkek $(\% 75,7)$, bekar $(\% 88,6)$, öğrenci $(\% 67,1)$, üniversite öğrencisi/mezunu (\%80) ve aday hakem $(\% 45,7)$ oldukları görülmektedir. Yaş ortalaması 23,83 (yıl), hakemlik 
Koca, S., ve Yıldız, S.M. (2018). Futbol hakemlerini strese iten faktörler, iş tatmini ve iş performansı ilişkisinin incelenmesi. Spor Bilimleri Araştırmaları Dergisi, 3(2), 195-207.

yılı ortalaması 1,87 (yıl) olan futbol hakemlerinin büyük çoğunluğunun geliri 1300 TL ve altındadır.

\section{Geçerlik ve Güvenirlik Analizi Sonuçları}

\section{Futbol Hakemlerini Strese İten Faktörler Ölçeğinin Geçerlik ve Güvenirlik Sonuçları}

Futbol hakemlerini strese iten faktörler ölçeğinin faktör analizine uygunluğu Kaiser-MeyerOlkin (KMO) ve Bartlett's Sphericity testi ile incelenmiştir. Ortaya çıkan test sonuçlarına göre ölçeğin KMO $(0,862)$ değerinin mükemmel olduğu anlaşılmıştır. Bartlett's Sphericity testi sonucu ise anlamlıdır $\left(\chi^{2}=1407,712 ; d f=91 ; p=0,000\right)$. Dolayısıyla bu sonuçlar ölçeğin faktör analizine uygun olduğunu göstermektedir.

Tablo 2: Futbol hakemlerini strese iten faktörler ölçeğinin geçerlik sonuçları

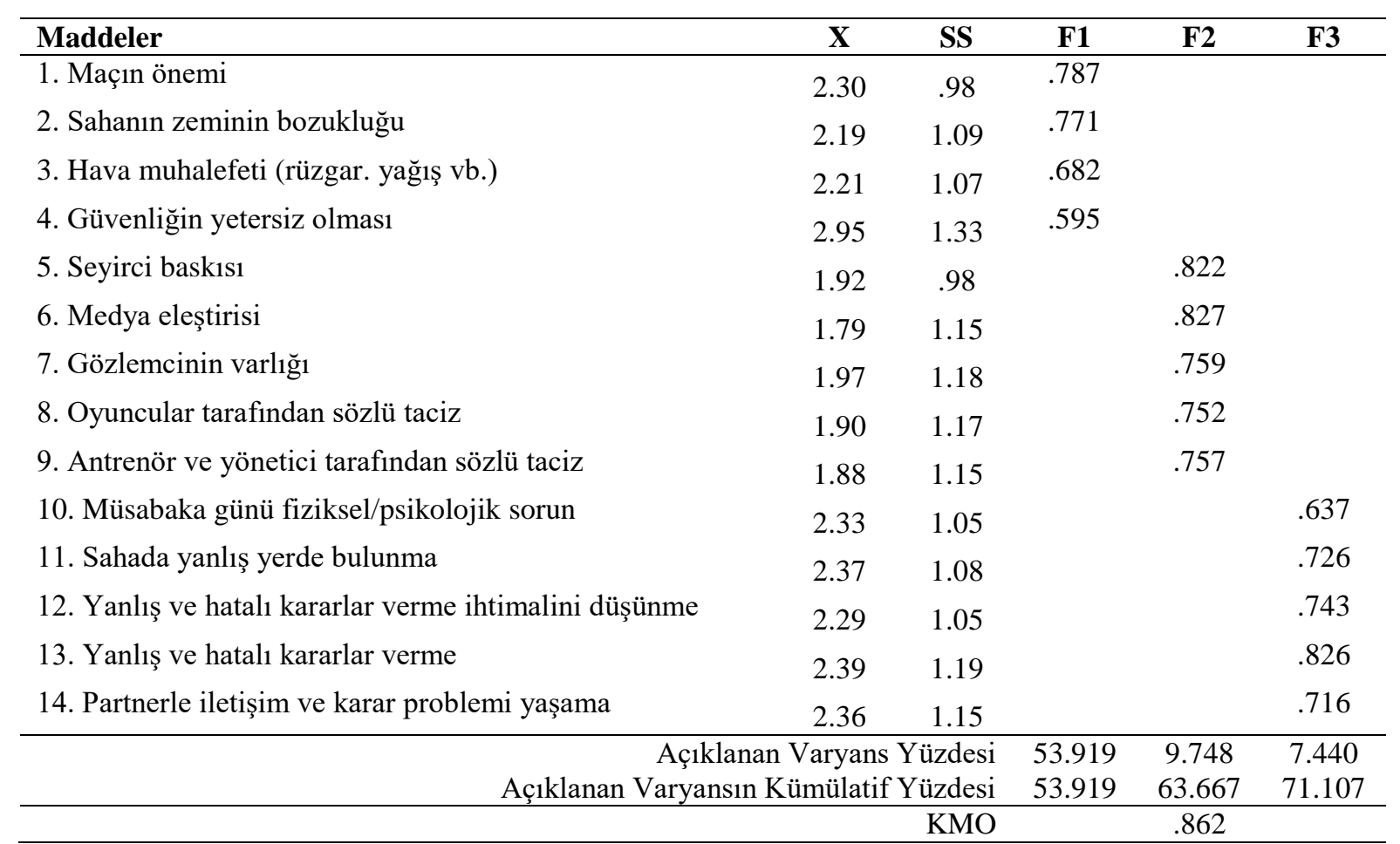

F1=D1ş Faktörler; F2=Sosyal Faktörler; F3=Kişisel Faktörler

Daha sonra ölçeğe varimax rotasyonuyla temel bileşenler analizi uygulanmış, buna göre, maddelerin 3 boyuta ayrıldığı görülmüştür (İlk boyut 4 maddeden, 2. boyut 5 maddeden, 3 . boyut 5 maddeden oluşmaktadır). İlk boyuta "dış faktörler", ikinci boyuta "sosyal faktörler", üçüncü boyuta ise "kişisel faktörler" adı verilmiştir. Ölçekte yer alan maddelerin faktör yükleri 0,595 ile 0,827 arasında değişmektedir (Tablo 2). 
Koca, S., ve Yıldız, S.M. (2018). Futbol hakemlerini strese iten faktörler, iş tatmini ve iş performansı ilişkisinin incelenmesi. Spor Bilimleri Araştırmaları Dergisi, 3(2), 195-207.

Tablo 3: Futbol hakemlerini strese iten faktörler ölçeğinin güvenirlik sonuçları

\begin{tabular}{|c|c|c|c|c|}
\hline Maddeler & $\begin{array}{c}\text { Madde } \\
\text { Silindiğinde } \\
\text { Ölçek } \\
\text { Ortalaması }\end{array}$ & $\begin{array}{c}\text { Madde } \\
\text { Silindiğinde } \\
\text { Ölçek } \\
\text { Varyansı }\end{array}$ & $\begin{array}{c}\text { Madde } \\
\text { Toplam } \\
\text { Korelasyonu }\end{array}$ & $\begin{array}{c}\text { Madde } \\
\text { Silindiğinde } \\
\text { Cronbach's } \\
\text { Alpha } \\
\text { Değeri } \\
\end{array}$ \\
\hline 1. Maçın önemi & 28.5857 & 119.554 & .510 & .932 \\
\hline 2. Sahanın zeminin bozukluğu & 28.7000 & 117.737 & .524 & .931 \\
\hline 3. Hava muhalefeti (rüzgar. yağış vb.) & 28.6786 & 115.284 & 648 & .928 \\
\hline 4. Güvenliğin yetersiz olması & 27.9429 & 113.320 & .574 & .931 \\
\hline 5. Seyirci baskısı & 28.9714 & 115.697 & .700 & .926 \\
\hline 6. Medya eleştirisi & 29.1000 & 111.846 & .749 & .925 \\
\hline 7. Gözlemcinin varlığg & 28.9214 & 112.764 & .685 & .927 \\
\hline 8. Oyuncular tarafindan sözlü taciz & 28.9929 & 111.072 & .765 & .924 \\
\hline 9. Antrenör ve yönetici tarafından sözlü taciz & 29.0071 & 110.986 & .789 & .923 \\
\hline 10. Müsabaka günü fiziksel/psikolojik sorun & 28.5571 & 115.443 & .656 & .928 \\
\hline 11. Sahada yanlış yerde bulunma & 28.5214 & 114.280 & .687 & .927 \\
\hline $\begin{array}{l}\text { 12. Yanlış ve hatalı kararlar verme ihtimalini } \\
\text { düşünme }\end{array}$ & 28.6000 & 112.414 & .800 & .923 \\
\hline 13. Yanlış ve hatalı kararlar verme & 28.5000 & 110.871 & .759 & .924 \\
\hline 14. Partnerle iletişim ve karar problemi yaşama & 28.5286 & 113.834 & .663 & .927 \\
\hline Cronbach's Alpha & \multicolumn{4}{|c|}{.932} \\
\hline
\end{tabular}

Diğer taraftan futbol hakemlerini strese iten faktörler ölçeğinin iç tutarlılığının belirlenmesi amacıyla gerçekleştirilen güvenirlik analizinde Cronbach Alpha değerinin 0,932 olduğu görülmüştür. Ayrıca, hiçbir maddenin toplam korelasyon ile negatif ilişkisi söz konusu değildir. Tüm bu değerler ölçeğin iç tutarlılığının çok iyi düzeyde olduğunu, yani "yüksek derecede güvenilir" olduğunu göstermektedir (Tablo 3).

\section{Futbol Hakemleri İş Tatmini Ölçeğinin Geçerlik ve Güvenirlik Sonuçlart}

Futbol hakemleri iş tatmini ölçeğinin faktör analizine uygunluğu Kaiser-Meyer-Olkin (KMO) ve Bartlett's Sphericity testi ile incelenmiştir. Ortaya çıkan test sonuçlarına göre ölçeğin KMO $(0,858)$ değerinin mükemmel olduğu anlaşılmıştır. Bartlett's Sphericity testi sonucu ise anlamlıdır $\left(\chi^{2}=697,406 ; d f=45 ; p=0,000\right)$. Dolayısıyla bu sonuçlar ölçeğin faktör analizine uygun olduğunu göstermektedir.

Daha sonra ölçeğe varimax rotasyonuyla temel bileşenler analizi uygulanmış, buna göre, maddelerin 2 boyuta ayrıldığı görülmüştür (İlk boyut 5 maddeden, 2. boyut 5 maddeden oluşmaktadır). İlk boyuta "içsel tatmin", ikinci boyuta "dışsal tatmin" adı verilmiştir. Ölçekte yer alan maddelerin faktör yükleri 0,545 ile 0,856 arasında değişmektedir (Tablo 4). 
Koca, S., ve Yıldız, S.M. (2018). Futbol hakemlerini strese iten faktörler, iş tatmini ve iş performansı ilişkisinin incelenmesi. Spor Bilimleri Araştırmaları Dergisi, 3(2), 195-207.

Tablo 4: Futbol hakemleri iş tatmini ölçeğinin geçerlik sonuçları

\begin{tabular}{|c|c|c|c|c|}
\hline Maddeler & $\mathbf{X}$ & SS & F1 & F2 \\
\hline 1. İşim (hakemliğim) yeteneklerimi yerine getirme firsatı veriyor. & 3.95 & 1.05 & .697 & \\
\hline 2. İşimden (hakemliğimden) başarı duygusu alıyorum. & 4.24 & .92 & .856 & \\
\hline $\begin{array}{l}\text { 3. İşim (hakemliğim) kişisel gelişimimi sağliyor ve ben de bundan } \\
\text { memnunum. }\end{array}$ & 4.32 & .90 & .842 & \\
\hline 4. İşimi (hakemliğimi) yapma hususunda kendimi yeterli buluyorum & 4.26 & .91 & .843 & \\
\hline 5. İşimi (hakemliği) anlamlı buluyorum. & 4.47 & .74 & .680 & \\
\hline $\begin{array}{l}\text { 6. İş yerinden (il hakem kurulundan) ve bana sağladığg olanaklardan } \\
\text { memnunum. }\end{array}$ & 4.19 & .91 & & .564 \\
\hline $\begin{array}{l}\text { 7. Diğer arkadaşlarımla karşılaştırdığımda (hakemlik) ücretinden } \\
\text { memnunum. }\end{array}$ & 3.54 & 1.28 & & .595 \\
\hline 8. İşim (hakemlik) bana yükselme. kariyer firsatı sunuyor. & 4.17 & .91 & & .846 \\
\hline $\begin{array}{l}\text { 9. Diğer çalışma arkadaşlarımla (hakemlerle) iyi bir şekilde } \\
\text { geçiniyorum. }\end{array}$ & 4.37 & .79 & & 688 \\
\hline 10. İşimi (hakemliği) iyi yaptığım zaman övgü alırım. & 4.42 & .64 & & .545 \\
\hline \multicolumn{3}{|c|}{ Açıklanan Varyans Yüzdesi } & $\begin{array}{l}50.021 \\
11.214\end{array}$ & $\begin{array}{l}50.021 \\
61.235\end{array}$ \\
\hline & & KMO & \multicolumn{2}{|c|}{.858} \\
\hline
\end{tabular}

F1=̧̇̇sel Tatmin; F2=Dışsal Tatmin

Diğer taraftan futbol hakemleri iş tatmini ölçeğinin iç tutarlılığının belirlenmesi amacıyla gerçekleştirilen güvenirlik analizinde Cronbach Alpha değerinin 0,871 olduğu görülmüştür. Ayrıca, hiçbir maddenin toplam korelasyon ile negatif ilişkisi söz konusu değildir. Tüm bu değerler ölçeğin iç tutarlılığının çok iyi düzeyde olduğunu, yani "yüksek derecede güvenilir" olduğunu göstermektedir (Tablo 5).

Tablo 5: Futbol hakemleri iş tatmini ölçeğinin güvenirlik sonuçları

\begin{tabular}{|c|c|c|c|c|}
\hline Maddeler & $\begin{array}{c}\text { Madde } \\
\text { Silindiğinde } \\
\text { Ölçek } \\
\text { Ortalaması }\end{array}$ & $\begin{array}{c}\text { Madde } \\
\text { Silindiğinde } \\
\text { Ölçek } \\
\text { Varyansı }\end{array}$ & $\begin{array}{c}\text { Madde } \\
\text { Toplam } \\
\text { Korelasyonu }\end{array}$ & $\begin{array}{c}\text { Madde } \\
\text { Silindiğinde } \\
\text { Cronbach's } \\
\text { Alpha } \\
\text { Değeri }\end{array}$ \\
\hline $\begin{array}{l}\text { 1. İşim (hakemliğim) yeteneklerimi yerine } \\
\text { getirme firsatı veriyor. }\end{array}$ & 38.0286 & 30.949 & .642 & .855 \\
\hline $\begin{array}{l}\text { 2. İşimden (hakemliğimden) başarı duygusu } \\
\text { alıyorum. }\end{array}$ & 37.7429 & 31.574 & .697 & .850 \\
\hline $\begin{array}{l}\text { 3. İşim (hakemliğim) kişisel gelişimimi sağlıyor } \\
\text { ve ben de bundan memnunum. }\end{array}$ & 37.6571 & 31.047 & .765 & .845 \\
\hline $\begin{array}{l}\text { 4. İşimi (hakemliğimi) yapma hususunda kendimi } \\
\text { yeterli buluyorum. }\end{array}$ & 37.7214 & 32.073 & .652 & .854 \\
\hline 5. İşimi (hakemliği) anlamlı buluyorum. & 37.5143 & 32.856 & .729 & .851 \\
\hline $\begin{array}{l}\text { 6. İş yerinden (il hakem kurulundan) ve bana } \\
\text { sağladığı olanaklardan memnunum. }\end{array}$ & 37.7929 & 32.568 & .597 & .858 \\
\hline $\begin{array}{l}\text { 7. Diğer arkadaşlarımla karşılaştırdığımda } \\
\text { (hakemlik) ücretinden memnunum. }\end{array}$ & 38.4429 & 32.723 & .356 & .888 \\
\hline $\begin{array}{l}\text { 8. İşim (hakemlik) bana yükselme, kariyer firsatı } \\
\text { sunuyor. }\end{array}$ & 37.8071 & 33.135 & .536 & .863 \\
\hline $\begin{array}{l}\text { 9. Diğer çalışma arkadaşlarımla (hakemlerle) iyi } \\
\text { bir şekilde geçiniyorum. }\end{array}$ & 37.6071 & 33.881 & .556 & .862 \\
\hline $\begin{array}{l}\text { 10. İşimi (hakemliği) iyi yaptığım zaman övgü } \\
\text { alırım. }\end{array}$ & 37.5571 & 34.752 & .583 & .862 \\
\hline Cronbach's Alpha & \\
\hline
\end{tabular}


Koca, S., ve Yıldız, S.M. (2018). Futbol hakemlerini strese iten faktörler, iş tatmini ve iş performansı ilişkisinin incelenmesi. Spor Bilimleri Araştırmaları Dergisi, 3(2), 195-207.

\section{Futbol Hakemleri İş Performansı Ölçeğinin Geçerlik ve Güvenirlik Sonuçları}

Futbol hakemleri iş performansı ölçeğinin faktör analizine uygunluğu Kaiser-Meyer-Olkin (KMO) ve Bartlett's Sphericity testi ile incelenmiştir. Ortaya çıkan test sonuçlarına göre ölçeğin KMO $(0,863)$ değerinin mükemmel olduğu anlaşılmıştır. Bartlett's Sphericity testi sonucu ise anlamlıdır $\left(\chi^{2}=444,593 ; d f=21 ; p=0,000\right)$. Dolayısıyla bu sonuçlar ölçeğin faktör analizine uygun olduğunu göstermektedir. Daha sonra ölçeğe varimax rotasyonuyla temel bileşenler analizi uygulanmış, buna göre, maddelerin tek boyutlu olduğu görülmüştür. Ölçekte yer alan maddelerin faktör yükleri 0,675 ile 0,832 arasında değişmektedir (Tablo 6).

Tablo 6: Futbol hakemleri iş performansi ölçeğinin geçerlik sonuçları

\begin{tabular}{|c|c|c|c|}
\hline Maddeler & $\mathbf{X}$ & SS & F1 \\
\hline 1. Maçı seyir zevkine ulaştırdığımdan eminim. & 4.03 & .90 & .726 \\
\hline 2. Maçta kuralları harfiyen uygularım. & 4.30 & .74 & .737 \\
\hline 3. Maçı yönetim kalitesine ulaştırdığımdan eminim. & 4.34 & .70 & .777 \\
\hline 4. Tartışmalı pozisyonlarda en hızlı şekilde çözüm üreten doğru kararlar veririm. & 4.21 & .76 & .832 \\
\hline $\begin{array}{l}\text { 5. Maçın havasını bozan (örneğin oyuncuların tartışması gibi) problemleri anında } \\
\text { çözerim. }\end{array}$ & 4.20 & .78 & .775 \\
\hline $\begin{array}{l}\text { 6. Müsabakanın ilerleyen dakikalarında oluşacak problemleri önceden } \\
\text { sezinleyerek büyümesine izin vermeden önlerim. }\end{array}$ & 4.32 & .75 & .786 \\
\hline \multirow[t]{3}{*}{ 7. Ben başarılı bir hakemim. } & 4.51 & .62 & .675 \\
\hline & $\begin{array}{l}\text { aryans } \\
\text { aülatif }\end{array}$ & $\begin{array}{l}\text { zdesi } \\
\text { zdesi }\end{array}$ & $\begin{array}{l}57.732 \\
57.732\end{array}$ \\
\hline & & $\mathrm{XMO}$ & .863 \\
\hline
\end{tabular}

F1= İş Performans1

Diğer taraftan futbol hakemleri iş performansı ölçeğinin iç tutarlılığının belirlenmesi amacıyla gerçekleştirilen güvenirlik analizinde Cronbach Alpha değerinin 0,875 olduğu görülmüştür. Ayrıca, hiçbir maddenin toplam korelasyon ile negatif ilişkisi söz konusu değildir. Tüm bu değerler ölçeğin iç tutarlılığının çok iyi düzeyde olduğunu, yani "yüksek derecede güvenilir" olduğunu göstermektedir (Tablo 7).

Tablo 7: Futbol hakemleri iş performansi ölçeğinin güvenirlik sonuçları

\begin{tabular}{lcccc}
\hline Maddeler & $\begin{array}{c}\text { Madde } \\
\text { Silindiğinde } \\
\text { Ölçek } \\
\text { Ortalaması }\end{array}$ & $\begin{array}{c}\text { Madde } \\
\text { Silindiğinde } \\
\text { Ölçek } \\
\text { Varyansı }\end{array}$ & $\begin{array}{c}\text { Madde } \\
\text { Toplam } \\
\text { Korelasyonu }\end{array}$ & $\begin{array}{c}\text { Madde } \\
\text { Silindiğinde } \\
\text { Cronbach's } \\
\text { Alpha Değeri }\end{array}$ \\
\hline $\begin{array}{l}\text { 1. Maçı seyir zevkine ulaştırdığımdan eminim. } \\
\text { 2. Maçta kuralları harfiyen uygularım. }\end{array}$ & 25.9071 & 11.509 & .625 & .864 \\
$\begin{array}{l}\text { 3. Maçı yönetim kalitesine ulaştırdığımdan } \\
\text { eminim. }\end{array}$ & 25.6357 & 12.248 & .637 & .860 \\
$\begin{array}{l}\text { 4. Tartışmalı pozisyonlarda en hızlı şekilde } \\
\text { çözüm üreten doğru kararlar veririm. }\end{array}$ & 25.6000 & 12.299 & .673 & .856 \\
$\begin{array}{l}\text { 5. Maçın havasını bozan (örneğin oyuncuların } \\
\text { tartışması gibi) problemleri anında çözerim. }\end{array}$ & 25.7286 & 11.652 & .746 & .845 \\
$\begin{array}{l}\text { 6. Müsabakanın ilerleyen dakikalarında } \\
\text { oluşacak problemleri önceden sezinleyerek }\end{array}$ & 25.7357 & 11.865 & .680 & .854 \\
$\begin{array}{l}\text { büyümesine izin vermeden önlerim. } \\
\text { 7. Ben başarılı bir hakemim. }\end{array}$ & 25.6214 & 11.978 & .691 & .853 \\
\hline \multicolumn{1}{c}{ Cronbach’s Alpha } \\
\hline
\end{tabular}




\section{Korelasyon Analizi Sonuçları}

Korelasyon sonuçları futbol hakemlerinin iş performansı üzerinde bazı değişkenlerin ilişkili olduğunu göstermektedir. Futbol hakemlerini strese iten faktörler $(r=-0,456)$ hakemlerin iş performansı ile anlamlı ve negatif ilişkilidir $(p<0,01)$. Alt boyutlar incelendiğinde; "dişsal faktörler" $(r=-0,396)$, "sosyal faktörler" $(r=-0,393)$ ve "kişisel faktörler" $(r=-0,405)$ de hakemlerin iş performansı ile anlamlı ve negatif ilişkilidir $(p<0,01)$. Stresin iş performansı ile ilişkisi orta düzeydedir. Demografik değişkenlere göz atıldığında, cinsiyetin iş performansı ile ilişkisi anlamlı ve negatif iken $(r=-0,316 ; p<0,01)$, yaş $(r=0,230 ; p<0,01)$, meslek $(r=0,238 ; p<0,01)$, gelir durumu $(r=0,253 ; p<0,01)$, hakemlik y1lı $(r=0,167 ; p<0,05)$ ve hakemlik klasmanı $(r=0,251 ; p<0,01)$ ile anlamlı ve pozitiftir (Tablo 8$)$.

Cinsiyet açısından erkeklerin kadınlara göre iş performansı daha yüksektir. Yaş ve hakemlik yılı ilerledikçe futbol hakemlerinin iş performansı artmaktadır. $\mathrm{Bu}$ durum deneyim ile açıklanabilir. Hakemlerin deneyimleri arttıkça, buna bağlı olarak iş performansları da artmaktadır. Meslek sahibi ve geliri olan hakemler, diğerlerine göre iş performansı yüksektir. Mesleğin ve gelirin olması, hakemleri rahatlatan ve böylece iş performansını artıran bir unsur olarak görülebilir. Hakemlik klasmanı arttıkça iş performansının artması, hakemlerin daha fazla eğitim almasına ve üst düzeyde deneyim yaşamasına bağlanabilir.

İş tatmini sadece medeni durumla ilişkilidir. Bekar olanlar evlilere göre futbol hakemliğinden daha fazla tatmin olmaktadırlar.

Kadın hakemler erkeklere göre daha streslidir. Bu durum kadınların duygusal anlamda daha hassas olmalarına bağlanabilir. Yaş ve hakemlik yılı azaldıkça, bununla beraber hakemlik klasmanı azaldıkça stres artmaktadır. $\mathrm{Bu}$ durum hakemlerin tecrübe eksikliğinden kaynaklanabilir. Meslek sahibi olan hakemler meslek sahibi olmayanlara göre daha az stresli olduğu görülmektedir. Hakemlik dışında gelir olmasının stresi azalttığı söylenebilir.

Tablo 8: Değişkenlerin korelasyon analizi sonuçları

\begin{tabular}{|c|c|c|c|c|c|c|c|}
\hline Değişkenler & 1 & 2 & 3 & 4 & 5 & 6 & 7 \\
\hline 1. Cinsiyet & 1 & & & & & & \\
\hline 2. Yaş & $-.213^{*}$ & 1 & & & & & \\
\hline 3. Medeni durum & $.203^{*}$ & $-.549^{* *}$ & 1 & & & & \\
\hline 4. Meslek & $-.216^{*}$ & $.632^{* *}$ & $-.497^{* *}$ & 1 & & & \\
\hline 5. Eğitim durumu & .158 & $.301^{* *}$ & -.067 & .163 & 1 & & \\
\hline 6. Gelir durumu & $-.251^{* * *}$ & $.529^{* *}$ & $-.432^{* *}$ & $.651^{* *}$ & -.003 & 1 & \\
\hline 7. Hakemlik yılı & $-.305^{* *}$ & $.721^{* *}$ & $-.492^{* *}$ & $.592^{* * *}$ & .058 & $.546^{* *}$ & 1 \\
\hline 8. Klasman & $-.221^{* * *}$ & $.573^{* *}$ & $-.307^{* *}$ & $.532^{* *}$ & .060 & $.548^{* *}$ & $.738^{* *}$ \\
\hline 9. D1şsal faktörler & $.339^{* *}$ & $-.240^{* *}$ & $.228^{* *}$ & $-.242^{* *}$ & -.002 & $-.258^{* *}$ & $-.240^{* *}$ \\
\hline 10. Sosyal faktörler & $.385^{* *}$ & -.157 & .030 & $-.183^{*}$ & -.097 & $-.254^{* *}$ & $-.197^{*}$ \\
\hline 11. Kişisel faktörler & $.372^{* *}$ & $-.198^{*}$ & .112 & $-.187^{*}$ & -.019 & $-.221^{* *}$ & $-.206^{*}$ \\
\hline 12. İçsel tatmin & -.013 & .017 & $.180^{*}$ & .039 & .125 & .155 & .053 \\
\hline 13. Dişsal tatmin & .060 & $-.205^{*}$ & $.259^{* *}$ & -.073 & .001 & .039 & -.166 \\
\hline 14. Stres & $.420^{* *}$ & $-.226^{* *}$ & .137 & $-.233^{* *}$ & -.047 & $-.280^{* * *}$ & $-.245^{* *}$ \\
\hline 15. İş tatmini & .023 & -.093 & $.239^{* *}$ & -.014 & .076 & .113 & -.052 \\
\hline 16. İş performansı & $-.316^{* * *}$ & $.230^{* *}$ & -.089 & $.238^{* *}$ & .078 & $.253^{* *}$ & $.167^{*}$ \\
\hline
\end{tabular}


Koca, S., ve Yıldız, S.M. (2018). Futbol hakemlerini strese iten faktörler, iş tatmini ve iş performansı ilişkisinin incelenmesi. Spor Bilimleri Araştırmaları Dergisi, 3(2), 195-207.

Tablo 8: Değişkenlerin korelasyon analizi sonuçları (devam)

\begin{tabular}{|c|c|c|c|c|c|c|c|c|}
\hline Değgişkenler & 8 & 9 & 10 & 11 & 12 & 13 & 14 & 15 \\
\hline \multicolumn{9}{|l|}{ 1. Cinsiyet } \\
\hline \multicolumn{9}{|l|}{ 2. Yaş } \\
\hline \multicolumn{9}{|l|}{ 3. Medeni durum } \\
\hline \multicolumn{9}{|l|}{ 4. Meslek } \\
\hline \multicolumn{9}{|l|}{ 5. Eğitim durumu } \\
\hline \multicolumn{9}{|l|}{ 6. Gelir durumu } \\
\hline \multicolumn{9}{|l|}{ 7. Hakemlik yılı } \\
\hline 8. Klasman & 1 & & & & & & & \\
\hline 9. Dişsal faktörler & $-.219^{* *}$ & 1 & & & & & & \\
\hline 10. Sosyal faktörler & $-.245^{* *}$ & $.558^{* *}$ & 1 & & & & & \\
\hline 11. Kişisel faktörler & $-.209^{*}$ & $.637^{* *}$ & $.716^{* *}$ & 1 & & & & \\
\hline 12. İçsel tatmin & .102 & -.138 & $-.453^{* *}$ & $-.298^{* *}$ & 1 & & & \\
\hline 13. Dişsal tatmin & -.091 & -.093 & $-.176^{*}$ & -.115 & $.636^{* *}$ & 1 & & \\
\hline 14. Stres & $-.258^{* *}$ & $.830^{* *}$ & $.880^{* *}$ & $.901^{* *}$ & $-.347^{* *}$ & -.149 & 1 & \\
\hline 15. İş tatmini & .015 & -.130 & $-.361^{* * *}$ & $-.237^{* *}$ & $.921^{* * *}$ & $.886^{* *}$ & $-.284^{* *}$ & 1 \\
\hline 16. İş performansı & $.251^{* * *}$ & $-.396^{* * *}$ & $-.393^{* *}$ & $-.405^{* *}$ & $.193^{*}$ & $.232^{* *}$ & $-.456^{* *}$ & $233^{* *}$ \\
\hline
\end{tabular}

\section{Hiyerarşik Regresyon Analizi Sonuçları}

Hiyerarşik regresyon analizinde Model 1'de "stres iten faktörler" bağımsız değişken, "iş tatmini" bağımlı değişken; Model 2'de "strese iten faktörler" bağımsız değişken, "iş performansı" bağımlı değişken; Model 3'te "strese iten faktörler" ile "iş tatmini" bağımsız değişken, "iş performansı" bağımlı değişken olarak incelenmiştir. Model 2'de -,456 olan strese iten faktörlerin $\beta$ değeri Model 3'te -,425'e düşmüş, ancak anlamlılığını devam ettirmiştir. Bunun yanında aracı değişken olan iş tatmini anlamlılığını yitirmiştir. Bu durum iş tatmininin, strese iten faktörler ile iş performansı arasında aracılık etkisinin bulunmadığını göstermektedir. Sonuç olarak hipotez 1 ve hipotez 2 kabul edilirken, hipotez 3 reddedilmiştir. Buna göre strese iten faktörlerin futbol hakemlerinin iş tatmini ve iş performansını direk olarak etkilediği söylenebilir (Tablo 9).

Tablo 9: Hiyerarşik regresyon analizi sonuçları

\begin{tabular}{|c|c|c|c|}
\hline Değişkenler & $\begin{array}{c}\text { İş Tatmini } \\
\beta \\
\end{array}$ & $\begin{array}{c}\text { İş Performansı } \\
\beta \\
\end{array}$ & $\begin{array}{c}\text { İş Performansı } \\
\beta \\
\end{array}$ \\
\hline \multicolumn{4}{|l|}{ Model 1} \\
\hline Stres & $-.284^{*}$ & & \\
\hline$F$ & 12.067 & & \\
\hline$R^{2}$ & .080 & & \\
\hline Düzeltilmiş $R^{2}$ & .074 & & \\
\hline \multicolumn{4}{|l|}{ Model 2} \\
\hline Stres & & $-.456^{* *}$ & \\
\hline$F$ & & 36.327 & \\
\hline$R^{2}$ & & .208 & \\
\hline Düzeltilmiş $R^{2}$ & & .203 & \\
\hline \multicolumn{4}{|c|}{ Model 2 ve Model 3} \\
\hline Stres & & & $-.425^{* *}$ \\
\hline İş Tatmini & & & .113 \\
\hline$F$ & & & 19.324 \\
\hline$R^{2}$ & & & .220 \\
\hline Düzeltilmiş $R^{2}$ & & & .209 \\
\hline
\end{tabular}


Koca, S., ve Yıldız, S.M. (2018). Futbol hakemlerini strese iten faktörler, iş tatmini ve iş performansı ilişkisinin incelenmesi. Spor Bilimleri Araştırmaları Dergisi, 3(2), 195-207.

\section{TARTIŞMA ve SONUÇ}

Literatürde hakemlere yönelik birtakım araştırmalar bulunsa da (Unutmaz ve Gençer, 2017) futbol hakemleri bağlamında stres, iş tatmini ve iş performansı arasındaki ilişkileri belirleme üzerine yapılmış bir çalışmaya rastlanmamıştır. Ancak, hakemlere yönelik stres konulu bir takım çalışmalar mevcuttur. Çakmak (2011) tarafından faal futbol hakemlerinin stres kanyaklarının tespitine yönelik yapılan araştırmada, futbol hakemlerinin stres kaynaklarını 'bireysel faktörler', 'çevresel faktörler' ve 'örgütsel faktörler' olarak tespit edilmiştir. Bu faktörler içerisinde futbol hakemlerini en fazla strese iten faktörün "bireysel faktörler" olduğu ortaya konulmuştur. Diğer bir araştırma basketbol hakemleri üzerinedir. Basketbol hakemlerinin stres kaynaklarını belirlemek üzere, Sayıner ve diğerleri (2009) tarafından yapılan araştırmada stres kaynakları 14 maddede toplanmıştır. Bunlar; partnerle problem yaşamak, yanlış ve hatalı karar vermek, başkaları tarafından fiziksel saldırı tehdidi, ağrı yaşamak veya sakatlık geçirmek, antrenör tarafından sözlü saldırı, çelişkili karar vermek, sahada yanlış yerde ve pozisyonda bulunmak, mekanikte hata yapmak, oyuncular tarafından sözlü saldırı, cinsel taciz, seyirciler tarafından sözlü saldırı, gözlemcinin varlığı, teknik faul çalmak, başka birinin sakatlığı (oyuncu, antrenör, partner) maddelerinden oluşmaktadır. Bu maddelerden "partneri ile problem yaşama" hakemleri en çok strese iten madde olarak tespit edilmiştir. Her iki araştırmada, maç kalitesine pozitif katkı sağlamak amacıyla, hakemleri etkileyen stres kaynaklarının bertaraf edilmesi ve stresle başa çıkabilme konusunda bir takım öneriler verilmiştir.

$\mathrm{Bu}$ araştırmada 14 maddeden ve 3 boyuttan ('kişisel faktörler', 'sosyal faktörler' ve 'dişsal faktörler'den) oluşan futbol hakemlerini strese iten faktörler ile yine hakemlere yönelik 7 maddeden oluşan iş performansı ölçeği geliştirilmiş ve analizler sonucunda geçerli ve güvenilir bulunmuştur. Ayrıca, futbol hakemlerini strese iten faktörler ile hakemlerin iş tatmini ve iş performansı arasında anlamlı ilişkiler tespit edilmiştir.

$\mathrm{Bu}$ araştırmanın sonuçlarına göre, strese iten faktörler futbol hakemlerinin iş tatmini ve iş performansinı anlamlı ve negatif olarak etkilemektedir. Yani, futbol hakemlerinin stres düzeyleri arttıkça, iş tatmini ve iş performansı azalmaktadır. Diğer taraftan, bu araştırmanın sonuçları iş tatmininin 'futbol hakemlerini strese iten faktörler' ile 'iş performansı' arasında "aracılık etkisinin bulunmadığını" göstermiştir. Bir başka deyişle, strese iten faktörler futbol hakemlerinin iş tatmini ile birlikte iş performansını direk olarak etkilemektedir.

$\mathrm{Bu}$ araştırmanın diğer sonuçlarına göre, futbol hakemlerinin iş performansını en yüksek düzeyde etkileyen faktör "kişisel stres faktörleri"dir. Bunu, "dışsal faktörler" ve ardından "sosyal faktörler" takip etmektedir. Demografik özellikler açısından, erkek hakemlerin kadın hakemlere göre iş performansı daha yüksektir. Hakemlerin yaşları ve hakemlik deneyimleri arttıkça, bununla birlikte hakemlik klasmanı arttıkça iş performansı artmaktadır. Diğer taraftan, bir mesleğe sahip olan ve geliri olan hakemler, meslek sahibi ve geliri olmayan hakemlere göre iş performansı daha yüksektir.

Sonuç olarak bu araştırma, daha az stresin futbol hakemlerinin iş tatminini ve iş performansını artıracağını göstermektedir. Hakemlerin düşük stres düzeyine sahip olmaları, maç esnasında kuralları hatasız uygulamalarına ve pozisyonları doğru değerlendirmelerine pozitif katkı sağlayacaktır. Özellikle ciddi hakem hatalarının sporda şiddet ve çirkin tezahürata (Türkmen ve diğ., 2013), basında nefret söylemine (Özsoy ve Yıldız, 2013) neden olabileceği dikkate alındığında, hakemlerin stres düzeyinin düşük olması gerektiği açıktır.

Bu bağlamda, stadyumların saha zemininin iyileştirilmesi, güvenliğin tam olarak sağlanması, medya yoluyla seyircilere yönelik pozitif yönlendirici programların yapılması, medyada 
Koca, S., ve Yıldız, S.M. (2018). Futbol hakemlerini strese iten faktörler, iş tatmini ve iş performansı ilişkisinin incelenmesi. Spor Bilimleri Araştırmaları Dergisi, 3(2), 195-207.

yapılan futbol programlarında hakemlere yönelik haksız eleştiri yapılmaması ve hakemlere yönelik stresle başa çıkma konusunda ilgili kurullar tarafından eğitimlerin düzenlenmesi önerisi verilebilir. Stresle başa çıkma eğitimleri, stresin neden olduğu istenmeyen durumları tersine çevirerek stresin muhtemel olumsuz sonuçlarını ortadan kaldıracaktır. Bir başka deyişle, stresle başa çıkabilen hakemin özgüveni yüksek olacak, böylece gelişen pozisyonlarda hızlı ve doğru karar verebilecektir. Bu araştırmadaki örneklem miktarının sınırlı olmasından dolayı araştırma sonuçları tüm hakemlere genellenemez. Dolayısıyla, elde edilen sonuçların genel olup olmadığını ve farklı örneklemlerde tutarlı olup olmadığını test etmek için ileride yapılacak benzer araştırmalara ihtiyaç bulunmaktadır.

\section{KAYNAKLAR}

Aziri, B. (2011). Job satisfaction: A literatüre review. Management Research and Practice, 3(4), 77-86.

Baron, R.M., \& Kenny, D.A. (1986). The moderator-mediator variable distinction in social psychological research: Conceptual, strategic, and statistical considerations. Journal of Personality and Social Psychology, 51(6), 1173-1182.

Carson, D., Gilmore, A., Perry, C., \& Gronhaug, K. (2001). Qualitative marketing research. London: Sage.

Çakmak, M.T. (2011). Faal futbol hakemlerinin stres kaynaklarının tespiti. Yüksek Lisans Tezi (Danışman: Prof.Dr.Güner Ekenci), Gazi Üniversitesi Sağllk Bilimler Enstitüsü, Beden Eğitimi ve Spor Anabilim Dalı, Spor Yönetim Bilimleri Programı, Ankara.

Chang, C.S., \& Chang, H.H. (2007). Effects of internal marketing on nurse job satisfaction and organizational commitment: Example of medical centers in Southern Taiwan. Journal of Nursing Research, 15(4), 265273.

Gümüştekin, G.E., ve Öztemiz, A.B. (2005). Örgütlerde stresin verimlilik ve performansla etkileşimi. Çukurova Üniversitesi Sosyal Bilimler Enstitüsü Dergisi, 14(1), 271-288.

Güney, S. (2012). Örgütsel davranış. Ankara: Nobel Yayınevi.

Özsoy, S., ve Yıldız, K. (2013). Türkiye'deki spor basınında nefret söylemi. International Journal Social Science Research, 2(2), 46-60.

Sayıner, B., Ekmekçi, R., Sözen, D., ve Anshell, M. (2009). Basketbol hakemlerinin stres kaynakları ve başa çıkma yöntemleri. İstanbul Ticaret Üniversitesi Fen Bilimleri Dergisi, 8(15), 27-36.

Schermerhorn, J.R., Hunt, J.G., \& Osborn, R.N. (1988). Managing Organizational Behavior. Third Edition, New York: John Wiley \& Sons, Inc.

Sonnentag, S., \& Frese, M. (2002). Performance concepts and performance theory. Psychological Management of Individual Performance. Edited by Sabine Sonnentag, John Wiley \& Sons, Ltd.

Tiryaki, Ş. (2000). Spor psikolojisi: Kavramlar, kuramlar ve uygulama. Ankara: İnkansa Ofset.

Türkmen, M., Yıldız, K., ve Zekioğlu, A. (2013). Sosyolojik açıdan sporda şiddet ve çirkin tezahüratın nedenlerinin araştırılması: Manisaspor taraftarları örneği. Spor Yönetimi ve Bilgi Teknolojileri Dergisi, 8(2), 15-34.

Unutmaz, V., ve Gençer, T. (2017). Antrenörlük yeterlilik ölçeği II'nin Türkçe uyarlama çalışması. Spor Bilimleri Araştırmaları Dergisi, 2(2), 69-78.

Yıldız, S.M. (2015a). Lider-üye etkileşimi, işyerinde mobbing ve mesleki tükenmişlik iliş̧kisi. Ankara: Detay Yayınevi.

Yıldiz, S.M. (2015b). The relationship between bullying and burnout: An empirical investigation of Turkish professional football players. Sport, Business and Management: An International Journal, 5(1), 6-20. 